\title{
CLOVER DRYING PROCESS BY FORCED CONVECTION
}

\author{
Pavel Kic \\ Czech University of Life Sciences Prague \\ kic@tf.czu.cz
}

\begin{abstract}
The aim of this paper is to inform about the experimental and theoretical investigations of red clover (Trifolium pratense) drying by forced convection. This research is focused on verification of influence of different air velocities on the drying process of red clover in thin layer in mild temperatures $\left(22^{\circ} \mathrm{C}\right)$ and rather high relative humidity of air $(70 \%)$. The initial moisture content of clover was determined by gravimetric method using the hot air drying in the electric oven. Special device for convection drying with air flow passing through material from the bottom through supporting trays with a sieve (dimensions of mesh $3 \times 4 \mathrm{~mm}$ ) by constant temperature was used for drying when the air velocity was $0 \mathrm{~m} \cdot \mathrm{s}^{-1}, 0.7 \mathrm{~m} \cdot \mathrm{s}^{-1}, 1 \mathrm{~m} \cdot \mathrm{s}^{-1}, 1.2 \mathrm{~m} \cdot \mathrm{s}^{-1}$ and $2.0 \mathrm{~m} \cdot \mathrm{s}^{-1}$. Changes of clover samples were determined from the measured values of weight using the gravimetric methods. The evaluation of the measurement results was focused on the curves of the drying rate, changes in the water content and changes of moisture depending on the time and their mutual relations, which are important for description of drying. To achieve humidity of $55 \%$, which would correspond to a request for storage in the form of red clover haylage (DM $45 \%$ ), drying by forced convection for 20 hours is sufficient, in the case of drying by natural convection with zero velocity it would require 40 hours. The experimental data create the background for calculation of the main parameters useful for description and modelling of the drying process, e.g., for decision of the optimum drying time.
\end{abstract}

Keywords: air, drying time, forced drying, natural drying, moisture.

\section{Introduction}

Red clover (Trifolium pratense) is widely grown as a fodder crop, valued for its high protein and minerals content, therefore it is sown for feeding cattle. It is also very useful in the system of crop rotation. It is because its nitrogen fixation, which increases soil fertility. The big advantage of clover is that in the Czech Republic it is growing in almost all altitudes. Red clover is most often harvested and conserved as hay, but can also be made into haylage or silage. The differences are according to the moisture or dry matter (DM) content.

Red clover, if properly harvested and stored, provides high-quality forage. Red clover is most often stored as haylage since it is difficult to store it as dry hay. Small particles of dry leaves in hay create dust and increase losses of feed material. DM is one of the fundamental characteristics in conservation of red clover $[1 ; 2]$. The DM content in fresh plants varies depending on the weather and on phenophases (age) in a wide range from 11 to $25 \%$. At the younger vegetation the DM content of red clover is lower, which requires long drying, but there is also a lower fibre content and improved digestibility of forage. During conservation it is necessary to increase the amount of dry matter at least to $35 \%$ (preferably $40 \%$ ) for the production of silage (suitable technological process using horizontal or tower silos). The economic evaluation of hay and haylage relation is presented in [3].

Red clover is most often stored as haylage since it is difficult to store it as dry hay. Small particles of dry leaves in hay create dust and increase losses of feed material. For production of haylage (silage with higher DM) it is necessary to increase the DM content to $45 \%$ (in horizontal or tower silos), for production of round bale wrapped in foil from 45 to $65 \%$. DM content of 75-85\% allows storage of forage in round bales without using the packaging film (under shelter) or in hayloft for longer periods. In the production of uncoated hay bales it is needed to prevent mold growth by increased DM content at least to $75 \%$.

Red clover is more difficult to cure for hay. For production of quality hay the DM 80-87 \% should be achieved. High-quality red clover hay should be green, soft to the touch, with a high proportion of leaves, smelling well and without admixtures. Moisture level should not be higher than $15 \%$.

Drying time and temperature together with the moisture influence the quality of the final dry fodder. Low temperatures have positive influence on the quality of biological materials, but require longer processing time. There are many different applications of drying for the agricultural [4-6] purposes. Problems of natural drying applied to drying of special plants are solved also in some scientific publications, e.g. [7]. 
The increased air velocity for convection or suitable material preparation can influence the drying process positively. But too high air velocity, needed to accelerate the drying process, can cause problems with losses of light particles particularly at the final stage of drying when forage has low water content and thus low density of small particles. In practice, sometimes DM is not sufficient in the production or storage of hay, haylage or silage, or on the contrary, DM is too high, which can cause higher losses of fodder. DM is an important determinant of intake by animals (Pond \& Pond, 2000). The attention of fodder crop drying under artificial conditions is paid in different scientific publications, e.g. [9; 10].

The aim of this work is to bring some new experimental and theoretical investigations of red clover drying by forced convection with air flows of different air velocities going from the bottom through trays with layers of fodder up. It could help in summarization of data and information about the drying conditions, e.g., to help in processes and methods for successful hay preparation in wet and rainy conditions.

\section{Materials and methods}

The laboratory measurements were carried out at the Faculty of Engineering, Czech University of Life Sciences Prague during summer weather conditions in July and August 2016. The technical equipment used for the experiments was a forced convection system of own design $[11 ; 12]$, which consisted of four vertical drying chambers.

Each of the drying chambers - a space in which a perforated tray with a sample was placed allows independent measurements during drying at different flow rates of drying air. The airflow delivered by the fan of $120 \mathrm{~mm}$ diameter is controlled by fan revolutions.

To research in the drying kinetics, the red clover samples, which were cut up into a particle length from 2 to $5 \mathrm{~cm}$, were placed in a thin layer about $50 \mathrm{~mm}$ on the sieve tray with mesh $3 \times 4 \mathrm{~mm}$ of total area approximately $20,400 \mathrm{~mm}^{2}$. Initial weight of one sample on one tray was approximately $120 \mathrm{~g}$. The forced drying was with the air velocity in the drying chambers $0.7 \mathrm{~m} \cdot \mathrm{s}^{-1}, 1 \mathrm{~m} \cdot \mathrm{s}^{-1}, 1.2 \mathrm{~m} \cdot \mathrm{s}^{-1}$ and $2.0 \mathrm{~m} \cdot \mathrm{s}^{-1}$. The results were compared with natural convection drying by the same temperature, but with the $0 \mathrm{~m} \cdot \mathrm{s}^{-1}$ air velocity.

Air speed was measured by the anemometer CFM 8901 Master (Hygrotec Messentechnik GmbH, Germany) with resolution $0.01 \mathrm{~m} \cdot \mathrm{s}^{-1}$ and accuracy $\pm 2 \%$ of final value. Air temperature and humidity were measured by the sensor FHA646-E1C connected to the data logger ALMEMO 2690-8 (Ahlborn $\mathrm{GmbH}$, Germany). The average temperature of drying air was $22 \pm 0.2^{\circ} \mathrm{C}$ and relative humidity $70 \pm 0.4 \%$.

The moisture content in the red clover samples was identified by gravimetric measurement in regular time intervals. The samples were weighed during drying on the digital laboratory balance KERN-440-35N (KERN and SOHN GmbH , Germany) with maximum load weight $400 \mathrm{~g}$ and with resolution $0.01 \mathrm{~g}$ and the values were recorded. Each measuring tray was weighed during the first 1 hour every $15 \mathrm{~min}$, later during the next 2.5 hours every $30 \mathrm{~min}$ and after that every $60 \mathrm{~min}$. The total drying time $168 \mathrm{~h}$ was adapted to the need for determination of the lowest moisture content, which can be achieved by convective drying.

The DM content in red clover was identified by gravimetric measurement using an MEMERT UNB-200 (MEMMERT GmbH + Co. KG, Germany) air oven under temperature $105^{\circ} \mathrm{C}$. The samples were weighed on a Kern 440-35N laboratory balance in regular time intervals. The total drying time was adapted to the need for determination of the equilibrium moisture.

The following main parameters are calculated from the measured values of all red clover samples. Water content $u$ is defined as the ration of the weight of water $m_{W}$ contained in a solid to the weight of dry solid $m_{S}$, expressed in equation (1).

$$
u=\frac{m_{W}}{m_{S}}
$$

where $u$-water content, $\mathrm{g} \cdot \mathrm{g}^{-1}$

$m_{W}-$ weight of water, g;

$m_{S}-$ weight of dry matter, g. 
Moisture $w$ is the ratio of the weight of water $m_{W}$ contained in a solid to the mass of the humid solid $m=m_{S}+m_{W}$, expressed in equation (2).

$$
w=\frac{m_{W}}{m} \cdot 100,
$$

where $w$-moisture, \%;

$m$ - weight of humid solid, g.

Changes of the water content $d u$ during the time difference $d t$ describe the drying rate $N$ expressed in equation (3).

$$
N=\frac{d u}{d t}
$$

where $\quad N$ - drying rate, $\mathrm{g} \cdot \mathrm{g}^{-1} \cdot \min ^{-1}$;

$$
t \text { - time, min. }
$$

\section{Results and discussion}

The kinetics of the red clover drying process caused by forced and natural convection with air velocities $\left(0.7 \mathrm{~m} \cdot \mathrm{s}^{-1}, 1 \mathrm{~m} \cdot \mathrm{s}^{-1}, 1.2 \mathrm{~m} \cdot \mathrm{s}^{-1}, 2 \mathrm{~m} \cdot \mathrm{s}^{-1}\right.$ and $\left.0 \mathrm{~m} \cdot \mathrm{s}^{-1}\right)$ is described by the curves calculated according to the equations (1), (2) and (3) in Fig. 1-5. The whole convection drying time $168 \mathrm{~h}$ was sufficient to the maximal drop of the water content which can be achieved by convection of the air temperature $22{ }^{\circ} \mathrm{C}$ and relative humidity $70 \%$.

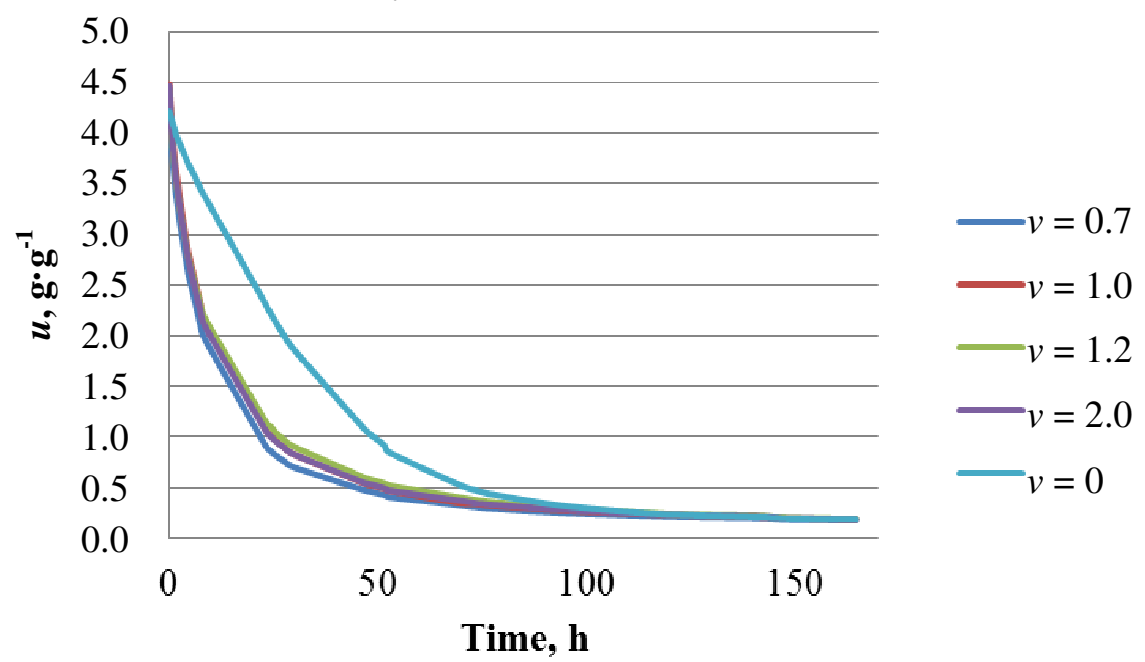

Fig. 1. Water content of all 5 red clover samples during the $168 \mathrm{~h}$ of convection drying with air velocities $0.7 \mathrm{~m} \cdot \mathrm{s}^{-1}, 1 \mathrm{~m} \cdot \mathrm{s}^{-1}, 1.2 \mathrm{~m} \cdot \mathrm{s}^{-1}, 2 \mathrm{~m} \cdot \mathrm{s}^{-1}$ and $0 \mathrm{~m} \cdot \mathrm{s}^{-1}$

Fig. 1 shows that all air velocities of forced drying including the smallest one $\left(v_{1}=0.7 \mathrm{~m} \cdot \mathrm{s}^{-1}\right)$ in comparison with natural convection $\left(v=0 \mathrm{~m} \cdot \mathrm{s}^{-1}\right)$ reduced the time of drying considerably. The small differences between the drying courses of forced drying with air velocities $\left(0.7 \mathrm{~m} \cdot \mathrm{s}^{-1}, 1 \mathrm{~m} \cdot \mathrm{s}^{-1}\right.$, $\left.1.2 \mathrm{~m} \cdot \mathrm{s}^{-1}, 2 \mathrm{~m} \cdot \mathrm{s}^{-1}\right)$ during the first 25 drying hours are more obvious if the curves are presented in Fig. 2.

The course of moisture during the first $168 \mathrm{~h}$ of convection drying is presented in Fig. 3. The decrease of moisture is significantly slower in the case of natural convection $\left(v=0 \mathrm{~m} \cdot \mathrm{s}^{-1}\right)$ than with forced convection. The differences between the drying courses of forced drying with air velocities $\left(0.7 \mathrm{~m} \cdot \mathrm{s}^{-1}, 1 \mathrm{~m} \cdot \mathrm{s}^{-1}, 1.2 \mathrm{~m} \cdot \mathrm{s}^{-1}, 2 \mathrm{~m} \cdot \mathrm{s}^{-1}\right)$ are very small.

The course of drying rate during the first 60 min of convection drying is presented in Fig. 4. The highest drying rate of all 5 red clover samples is during 10 minutes. In Fig. 4 a typical course of this drying process, which can be divided into three phases, is shown. In the first phase (initial drying period), there is a considerable increase of the drying rate where the dried material adapts to the new conditions of a heat and material balance during the drying. In the second phase (a short interval of 
maximum drying rate) is a reduction of moisture due to evaporation from the surface of the material particles.

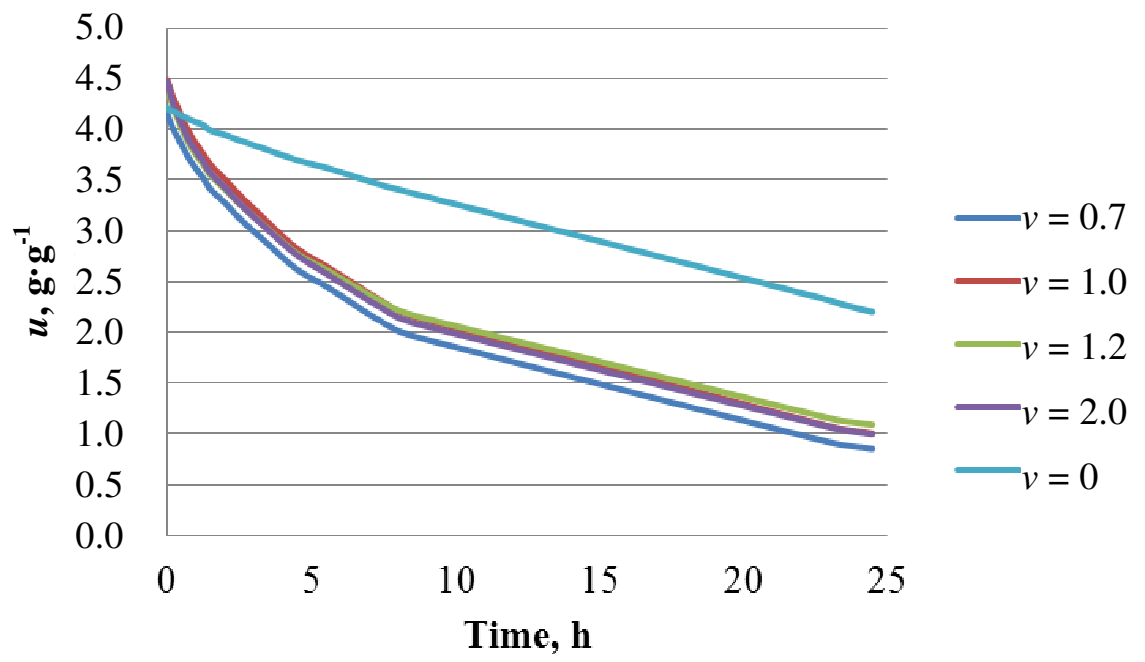

Fig. 2. Water content of all 5 red clover samples during the first $25 \mathrm{~h}$ of convection drying with air velocities $0.7 \mathrm{~m} \cdot \mathrm{s}^{-1}, 1 \mathrm{~m} \cdot \mathrm{s}^{-1}, 1.2 \mathrm{~m} \cdot \mathrm{s}^{-1}, 2 \mathrm{~m} \cdot \mathrm{s}^{-1}$ and $0 \mathrm{~m} \cdot \mathrm{s}^{-1}$

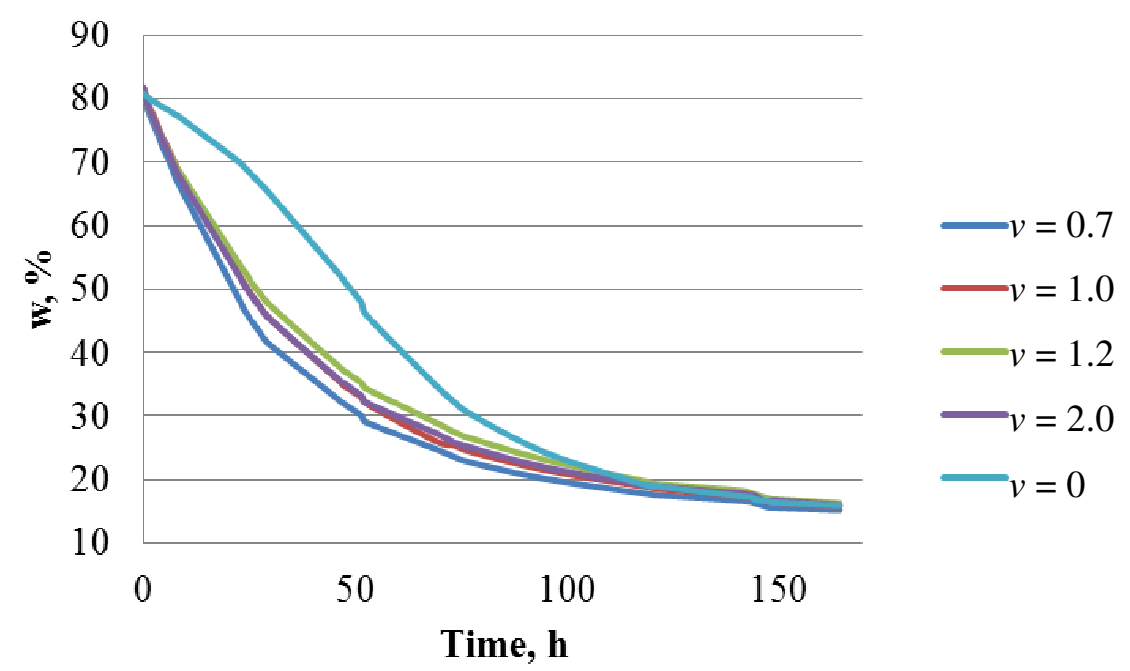

Fig. 3. Moisture of all 5 red clover samples during the first $168 \mathrm{~h}$ of convection drying with air velocities $0.7 \mathrm{~m} \cdot \mathrm{s}^{-1}, 1 \mathrm{~m} \cdot \mathrm{s}^{-1}, 1.2 \mathrm{~m} \cdot \mathrm{s}^{-1}, 2 \mathrm{~m} \cdot \mathrm{s}^{-1}$ and $0 \mathrm{~m} \cdot \mathrm{s}^{-1}$

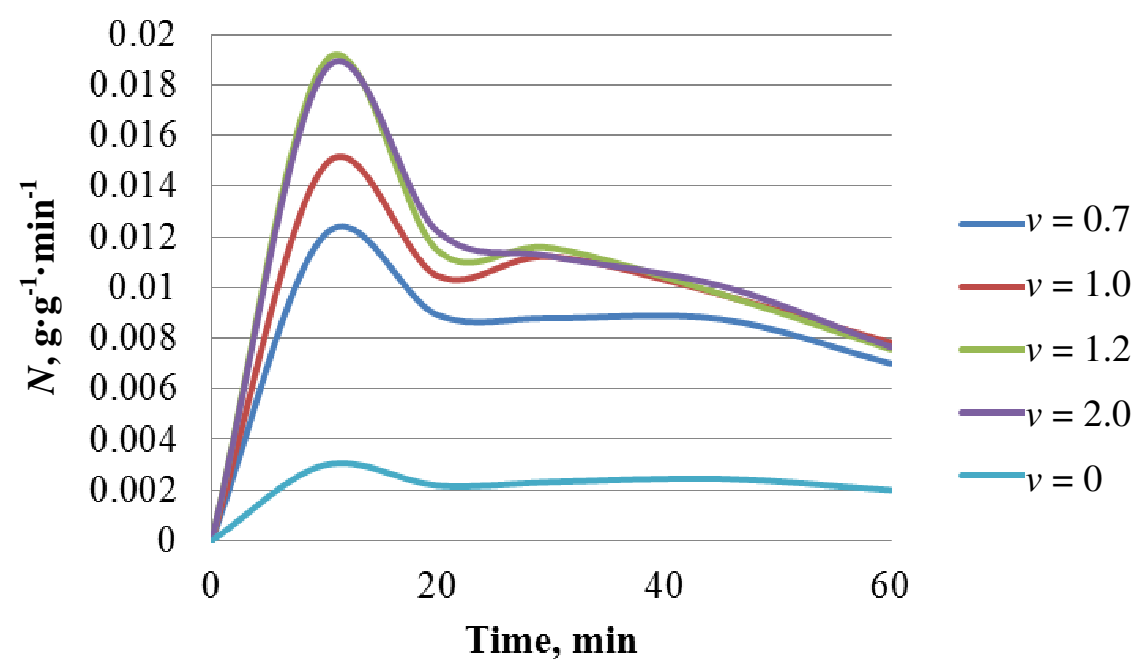

Fig. 4. Drying rate of all 5 red clover samples during the first 60 min of convection drying with air velocities $0.7 \mathrm{~m} \cdot \mathrm{s}^{-1}, 1 \mathrm{~m} \cdot \mathrm{s}^{-1}, 1.2 \mathrm{~m} \cdot \mathrm{s}^{-1}, 2 \mathrm{~m} \cdot \mathrm{s}^{-1}$ and $0 \mathrm{~m} \cdot \mathrm{s}^{-1}$ 
The last phase is a gradual reduction of the drying rate caused by the moisture slowly progressing and transferred through the material particles and vaporized inside the material. To study and see a more accurate statement and description of the whole drying process, it is possible to achieve by the shortest step dt. According to Fig. 4 the difference between the drying rate with the air velocity $1.2 \mathrm{~m} \cdot \mathrm{s}^{-1}\left(N=0.0189 \mathrm{~g} \cdot \mathrm{g}^{-1} \cdot \mathrm{min}^{-1}\right)$ and $2 \mathrm{~m} \cdot \mathrm{s}^{-1}\left(N=0.0186 \mathrm{~g} \cdot \mathrm{g}^{-1} \cdot \mathrm{min}^{-1}\right)$ is rather small. It is obvious that the drying rate with natural convection $\left(N=0.0029 \mathrm{~g} \cdot \mathrm{g}^{-1} \cdot \mathrm{min}^{-1}\right)$ is very low also during the first hour.

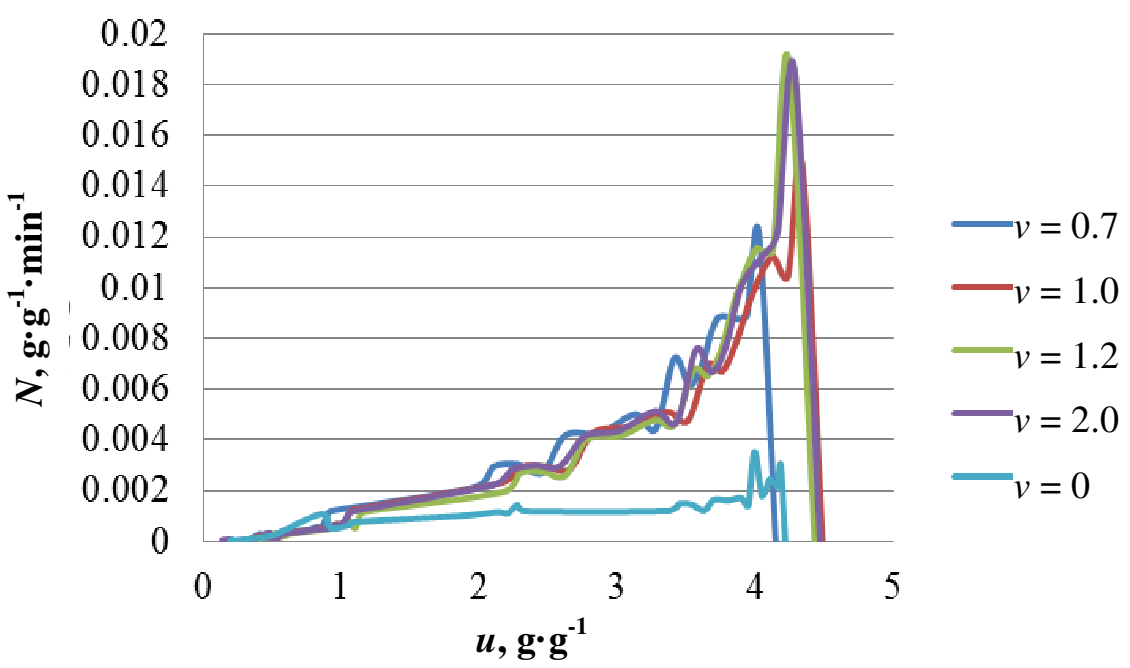

Fig. 5. Drying rate of all 5 red clover samples as a function of water content during convection drying with air velocities $0.7 \mathrm{~m} \cdot \mathrm{s}^{-1}, 1 \mathrm{~m} \cdot \mathrm{s}^{-1}, 1.2 \mathrm{~m} \cdot \mathrm{s}^{-1}, 2 \mathrm{~m} \cdot \mathrm{s}^{-1}$ and $0 \mathrm{~m} \cdot \mathrm{s}^{-1}$

The results of the research presented in Figs. 1-5 show the relatively small differences between certain parameters of the calculated drying process. The lines shown in the graphs are therefore in some cases in very tight location to each other, or even partially touch or overlap each other. Rather interesting is the dependence of the drying rate on the water content presented in Fig. 5, describing both very important parameters of the drying process. The best relation between the drying rate and the water content is achieved, if the water content is high and with higher air velocity of forced drying. It is well obvious also in this figure that the difference between drying with air velocities $1.2 \mathrm{~m} \cdot \mathrm{s}^{-1}$ and $2 \mathrm{~m} \cdot \mathrm{s}^{-1}$ is very small.

As an example of practical use of this research it is possible to determine from the measured and calculated results that the drying time to achieve the relative humidity of $15 \%$ (appropriate for hay) by forced convection of red clover in air of $22^{\circ} \mathrm{C}$ is very long, about $168 \mathrm{~h} \mathrm{(7} \mathrm{days).} \mathrm{The} \mathrm{achievement} \mathrm{of}$ these parameters by forced convection is in all cases of the tested air flow velocities.

To achieve the relative humidity of $55 \%$, which corresponds to a request for storage in the form of red clover haylage (DM $45 \%$ ), drying by forced convection for 20 hours is sufficient, in the case of drying by natural convection with zero velocity it would require 40 hours.

\section{Conclusions}

1. This research has been useful for verification of the influence of different air velocities on the drying process of red clover in thin layer and in mild temperatures $\left(22^{\circ} \mathrm{C}\right)$ and rather high relative humidity of air (70\%), which corresponds to more difficult harvest conditions.

2. It has been found that forced convection has a strong and positive influence on the drying time in comparison with free drying by natural convection. The differences between the results of drying with the air velocities $1.2 \mathrm{~m} \cdot \mathrm{s}^{-1}$ and $2 \mathrm{~m} \cdot \mathrm{s}^{-1}$ are very small, therefore $1.2 \mathrm{~m} \cdot \mathrm{s}^{-1}$ could be realized as an optimum. Higher air velocity could cause losses of small dry particles especially at the end of the drying process.

3. Future research should be focused on the study of other factors influencing the drying process expressed by the drying coefficient with the aim to achieve the suitable moisture for optimization of the drying time in different air temperatures. 


\section{References}

1. Maloun J. Technological equipment and main processes in the production of fodder. Prague: CULS, Faculty of Engineering, 2001. 201 p. (In Czech).

2. Bebb D.L. Mechanised livestock feeding. Oxford: BSP professional books, 1990. 209 p.

3. Bay T., Gildersleeve R., Barnett K. etc. How to price standing forage. Focus on Forage, vol. 9, no. 4, 2008, pp. 1-2

4. Aboltins A., Palabinskis J. New types of air heating solar collectors and their use in drying agricultural products. Agronomy Research, vol. 11, 2013, pp. 267-274.

5. Jokiniemi T., Mikkola H., Rossner H. etc. Energy savings in plant production. Agronomy Research, vol. 10, 2012, pp. 85-96.

6. Jokiniemi T., Jaakkola S., Turunen M. etc. Energy consumption in different grain preservation methods. Agronomy Research, vol. 12, 2014, pp. 81-94.

7. Aboltins A., Kic P. Research of some medical plants drying process. Proceedings of International Scientific Conference "Engineering for Rural Development". 2016, Jelgava, Latvia University of Agriculture, Latvia, pp. 1145-1150.

8. Pond W.G., Pond K.R. Introduction to animal science. New York: John Wiley \& sons, inc., 2000. $687 \mathrm{p}$.

9. Osorno F.L., Hensel O. Drying homogeneity of grass mixture components in a rotary drum. Drying Technology, vol. 30, 2012, pp. 1931-1935.

10. Adapa P.K., Schoenau G.J., Arinze E.A. Fractionation of alfalfa into leaves and stemps using a three pass rotary drum dryer. Biosystems Engineering, vol. 91, 2004, pp. 455-463.

11. Kic P., Liska R. Apparatus for drying loose or bulk materials. Utility model No. 23841. Prague: Industrial property Office, 2012, 5 p. (In Czech)

12. Kic P., Aboltins A. Convective drying of poultry manure by different air speeds. Proceedings of International Scientific Conference "Engineering for Rural Development". 2013., Jelgava, Latvia University of Agriculture, Latvia, pp. 121-125. 